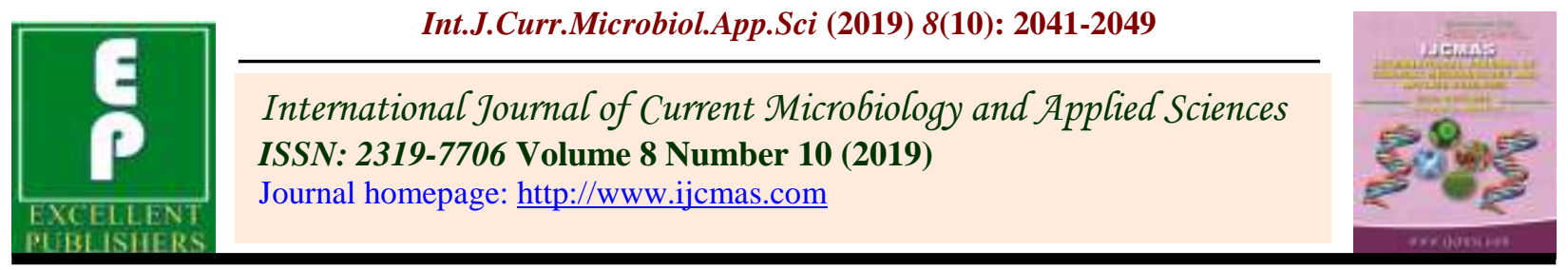

Original Research Article https://doi.org/10.20546/ijcmas.2019.810.238

\title{
Response of Greengram (Vigna radiata L. Wilczek) to Nutrients Influencing Yield, Uptake and Soil Fertility in Loamy Sand Soil under Dry Land Condition
}

\author{
Komalben K. Bhabhor ${ }^{1}$, Nandkishor I. Patel $^{2}$, Brijal R. Patel ${ }^{1}$ and M. M. Chaudhary ${ }^{3}$ \\ ${ }^{1}$ C.P. College of Agriculture, SDAU, S.K. Nagar, Gujarat, India \\ ${ }^{2}$ AICRPDA, CNRM, SDAU, S.K. Nagar, Gujarat, India \\ ${ }^{3}$ Centre for Natural Resources Management, SDAU, S.K. Nagar, Gujarat, India \\ *Corresponding author
}

\section{A B S T R A C T}

Keywords

Greengram, Yield,

N, P, S, PSB,

Content, Uptake and Economics

Article Info

Accepted:

15 September 2019

Available Online:

10 October 2019
The experiment was conducted during the Kharif season of the year 2018 at AICRP for Dry Land, Centre for Natural Resources Management, Sadarkrushinagar Datiwada Agricultural University, Sardarkrushinagr, Gujarat to study the "Effect of phosphorus, sulphur and biofertilizer on yield and available nutrient status of greengram (Vigna radiata L. Wilczek) in loamy sand under dry land condition". The results revealed that integrated application of $50 \mathrm{~kg} \mathrm{P}_{2} \mathrm{O}_{5} / \mathrm{ha}+20 \mathrm{~kg} \mathrm{~S} / \mathrm{ha}+\mathrm{PSB}$ registered significantly higher seed and stover yield, content of $\mathrm{P}$ and $\mathrm{S}$ in seed as well as stover and uptake of $\mathrm{N}, \mathrm{P}$ and $\mathrm{S}$ in seed as well as stover of greengram. The highest net realization and benefit : cost ratio (BCR) was obtained with the treatment $30 \mathrm{~kg} \mathrm{P}_{2} \mathrm{O}_{5} / \mathrm{ha}+20 \mathrm{~kg} \mathrm{~S} / \mathrm{ha}+\mathrm{PSB}$. The organic carbon content in soil remained unaffected due to different treatments. Significantly the highest phosphorus and sulphur build up in soil after harvest of the crop was observed under the treatment of $50 \mathrm{~kg} \mathrm{P}_{2} \mathrm{O}_{5} / \mathrm{ha}+20 \mathrm{~kg} \mathrm{~S} / \mathrm{ha}+\mathrm{PSB}$.

\section{Introduction}

Greengram (Vigna radiata L.) is commonly known as moong or golden gram. It belongs to family Leguminosae. The India is the largest producer and consumer of pulses. In India, kharif greengram occupies an area of about 40.70 lakh ha with a production of 19.01 lakh tonnes (DE and S, 2018-19). In Gujarat, kharif greengram occupies an area of about 63,000 ha with a production of 24,000 tonnes and the productivity is $381 \mathrm{~kg} / \mathrm{ha}$, respectively (DOA, 2018-19).
Phosphorus is a second major nutrient for plants because of their high requirement. It is also involved in controlling key enzyme reaction and in the regulation of metabolic pathways (Theodorou and Plaxton, 1993). Since the concentration of phosphorus in the soil solution is normally insufficient to support plant growth, continual replacement of soluble phosphorus from inorganic and organic source is necessary for crop growth (Chauhan et al., 1997). So, to meet the phosphorus requirements of crops phosphatic fertilizer are used. Sulphur is essential for synthesis of 
vitamins (Biotin and Thiamine), sulphur containing amino acids that are cystine, cysteine and methionine are a requisite for protein synthesis. It is also constituent of glutathione, a compound that plays a part in plant respiration and synthesis of essential oils. It has a number of oxidizing functions in plant nutrition and a constituent of $\mathrm{Fe}-\mathrm{S}$ proteins called Ferredoxin, responsible for transfer of electrons during the first phase of photosynthesis reaction (Marchner, 1995; Goswami, 1988 and Randall, 1988).

Seed inoculation with proper strain of phosphorus solubilizing bacteria is low cost input for enhancing yield, as it solubilizes the unavailable phosphorus into the available forms, which reduces the high cost of inorganic phosphatic fertilizer (Parveen et al. 2002). Phosphorus dissolving microorganisms have capacity to render insoluble form of phosphate more available to plant besides, metabolic product of soil microbes such as organic acids and humic substances form complexes with $\mathrm{Fe}$ and $\mathrm{Al}$ compounds, thereby reducing further fixation.

\section{Materials and Methods}

A field experiment on "Response of greengram (Vigna radiata L. Wilczek) to nutrients influencing yield, uptake and soil fertility in loamy sand soil under dry land condition". The field experiment was laid out on Plot No. 9 at AICRP for Dry land Agriculture, Centre for Natural Resources Management, Sardarkrushinagar Dantiwada Agricultural University, Sardarkrushinagar during kharif season of 2017-18. Total twelve treatments viz., $\mathrm{T}_{1}: 30 \mathrm{~kg} \mathrm{P}_{2} \mathrm{O}_{5} / \mathrm{ha}, \mathrm{T}_{2}: 40 \mathrm{~kg}$ $\mathrm{P}_{2} \mathrm{O}_{5} / \mathrm{ha}, \mathrm{T}_{3}: 50 \mathrm{~kg} \mathrm{P}_{2} \mathrm{O}_{5} / \mathrm{ha}, \mathrm{T}_{4}: 30 \mathrm{~kg}$ $\mathrm{P}_{2} \mathrm{O}_{5} / \mathrm{ha}+20 \mathrm{~kg} \mathrm{~S} / \mathrm{ha}, \mathrm{T}_{5}: 40 \mathrm{~kg} \mathrm{P}_{2} \mathrm{O}_{5} / \mathrm{ha}+20$ $\mathrm{kg} \mathrm{S} / \mathrm{ha}, \mathrm{T}_{6}: 50 \mathrm{~kg} \mathrm{P}_{2} \mathrm{O}_{5} / \mathrm{ha}+20 \mathrm{~kg} \mathrm{~S} / \mathrm{ha}, \mathrm{T}_{7}$ : $30 \mathrm{~kg} \mathrm{P}_{2} \mathrm{O}_{5} / \mathrm{ha}+\mathrm{PSB}, \mathrm{T}_{8}: 40 \mathrm{~kg} \mathrm{P}_{2} \mathrm{O}_{5} / \mathrm{ha}+$

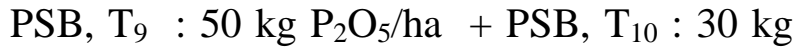
$\mathrm{P}_{2} \mathrm{O}_{5} / \mathrm{ha}+20 \mathrm{~kg} \mathrm{~S} / \mathrm{ha}+\mathrm{PSB}, \mathrm{T}_{11}: 40 \mathrm{~kg}$ $\mathrm{P}_{2} \mathrm{O}_{5} / \mathrm{ha}+20 \mathrm{~kg} \mathrm{~S} / \mathrm{ha}+\mathrm{PSB}$ and $\mathrm{T}_{12}: 50 \mathrm{~kg}$
$\mathrm{P}_{2} \mathrm{O}_{5} / \mathrm{ha}+20 \mathrm{~kg} \mathrm{~S} / \mathrm{ha}+\mathrm{PSB}$ were tried in randomized block design with three replications in loamy sand soil. The details of treatments tested in the present investigation are as follows:

Greengram cv. GM 4 was sown with spacing $40 \mathrm{~cm} \times 10 \mathrm{~cm}$ on $11^{\text {th }}$ July, 2018 and harvesting on $11^{\text {th }}$ September, 2018. Other cultural practices and plant protection measures were taken as per recommendation. The data on seed and stover yield were recorded from net plot and converted on hectare basis. The plant samples (seed and stover) were wet digested using di-acid mixture of $\mathrm{HNO}_{3}$ and $\mathrm{HClO}_{4}$ in 3:1 ratio. The acid extract prepared after digestion was used for estimation of $\mathrm{P}$ and $\mathrm{S}$. The total $\mathrm{N}$ content in seed and stover was estimated by Kjeldahl method using $\mathrm{N}$ analyzer (KELPLUS model). The observations of the study was to know the nutrient status of soil at harvest, a representative soil samples $(0-15 \mathrm{~cm}$ depth) from five spots of each plot after harvest of greengram crop were collected, composited and air dried in shade. These samples were then ground using wooden mortar and pestle and passed through $2 \mathrm{~mm}$ sieve and were analyzed for organic carbon by Walkley and Black titration and the available phosphorus $(\mathrm{kg} / \mathrm{ha})$ of soil was extracted with $0.5 \mathrm{M}$ sodium bicarbonate (1:20) and determined colorimetrically and soil available $\mathrm{S}$ was extracted with $0.15 \% \mathrm{CaCl}_{2}$.

The net realization was calculated by deducting the total cost of cultivation from the gross realization for each treatment. The benefit cost ratio (BCR) was calculated on the basis formula given below.

$\mathrm{BCR}=$ Net realization (Rs./ha) /cost of cultivation (Rs./ha).

The data related to each parameter of the experiment were statistically analyzed using MSTATC software. The purpose of analysis 
of variance was to determine the significant effect of treatments on greengram. LSD test at $5 \%$ probability level was applied when analysis of variance showed significant effect of treatment (Panse and Sukhatme 1985).

\section{Results and Discussion}

\section{Yields of greengram}

The data pertaining to seed and stover yield of greengram are presented in Table 1 showed that the treatment receiving $50 \mathrm{~kg} \mathrm{P}_{2} \mathrm{O}_{5} / \mathrm{ha}+$ $20 \mathrm{~kg} \mathrm{~S} / \mathrm{ha}+\mathrm{PSB}$ produced significantly higher seed (761 kg/ha) and stover yield $(131 \mathrm{~kg} / \mathrm{ha})$, but it was remained at par with all the treatments consisting of phosphorus, sulphur and biofertilizer treatments except $\mathrm{T}_{1}$, $\mathrm{T}_{2}, \mathrm{~T}_{3}$ and $\mathrm{T}_{7}$ and $\mathrm{T}_{1}, \mathrm{~T}_{2}, \mathrm{~T}_{9}$ and $\mathrm{T}_{7}$ for seed and stover, respectively.

The yield improvement was higher when phosphorous was applied along with sulphur and PSB. The significant increase in yield of greengram due to phosphorous, sulphur and PSB might be due to fact that phosphorus, sulphur and PSB had positive effect on greengram yields as phosphorus is known to play beneficial role in legume by promoting extensive root development and nodulation ensuring better nutritional environment for growth and finally the yield.

Sulphur also played important role in energy transformation and activation of enzymes, carbohydrate metabolism and also due to inoculation with PSB, which increased available phosphorus and favored higher absorption and utilization of $\mathrm{P}$ and plant nutrients and ultimately positive resultant effect on growth and yield attributes, which led to increase in seed and stover yield. These results are in the line of those reported by Patel et al. (2013), Manju et al. (2016), Das (2017), Sipai et al. (2016) and Serawat et al. (2018).

\section{Nutrient content}

Data pertaining to $\mathrm{N}, \mathrm{P}$ and $\mathrm{S}$ content in seed and stover of greengram are represented in Table 2.

\section{$\mathrm{N}$ content in seed and stover}

The data presented in Table 2 revealed that the differences in $\mathrm{N}$ content in seed and stover of greengram were found non significant.

\section{$P$ content in seed and stover}

The data pertaining to phosphorous content in seed and stover are given in Table 2 showed that the phosphorous content in seed and stover were significantly influenced due to different treatments. Significantly highest phosphorous content in seed $(0.637 \%)$ and stover $(0.182 \%)$ were found with treatment of viz., $50 \mathrm{~kg} \mathrm{P}_{2} \mathrm{O}_{5} / \mathrm{ha}+20 \mathrm{~kg} \mathrm{~S} / \mathrm{ha}+\mathrm{PSB}$, but it was at par with the treatments $40 \mathrm{~kg} \mathrm{P}_{2} \mathrm{O}_{5} / \mathrm{ha}+$ $20 \mathrm{~kg} \mathrm{~S} / \mathrm{ha}+\mathrm{PSB}, 30 \mathrm{~kg} \mathrm{P}_{2} \mathrm{O}_{5} / \mathrm{ha}+20 \mathrm{~kg} \mathrm{~S} / \mathrm{ha}$ $+\mathrm{PSB}$ and $50 \mathrm{~kg} \mathrm{P}_{2} \mathrm{O}_{5} / \mathrm{ha}+20 \mathrm{~kg} \mathrm{~S} / \mathrm{ha}$. The lowest phosphorous content in seed and stover was obtained under treatment receiving $30 \mathrm{~kg}$ $\mathrm{P}_{2} \mathrm{O}_{5} /$ ha. The significant increase of $\mathrm{P}$ content in seed and stover due to application of phosphorous, sulphur and PSB might be attributed to fact that synergistic effect among them had favorable effect on soil properties and makes more $\mathrm{P}$ available during crop growing season. These results are in close agreement with those reported by Manju et al. (2016) and Raj et al. (2017) in greengram crop.

\section{$S$ content in seed and stover}

Data pertaining to $\mathrm{S}$ content in seed and stover are presented in Table 2.

The sulphur content in seed and stover were significantly influenced due to different treatments. Application of $50 \mathrm{~kg} \mathrm{P}_{2} \mathrm{O}_{5} / \mathrm{ha}+20$ 
$\mathrm{kg} \mathrm{S} /$ ha + PSB recorded significantly higher S content in seed $(0.247 \%)$ and stover $(0.135$ $\%)$, but it was found at par with the treatments viz., $40 \mathrm{~kg} \mathrm{P}_{2} \mathrm{O}_{5} / \mathrm{ha}+20 \mathrm{~kg} \mathrm{~S} / \mathrm{ha}+\mathrm{PSB}, 30 \mathrm{~kg}$ $\mathrm{P}_{2} \mathrm{O}_{5} / \mathrm{ha}+20 \mathrm{~kg} \mathrm{~S} / \mathrm{ha}+\mathrm{PSB}$ and $50 \mathrm{~kg}$ $\mathrm{P}_{2} \mathrm{O}_{5} / \mathrm{ha}+20 \mathrm{~kg} \mathrm{~S} / \mathrm{ha}$ and in the same trend for stover but in addition of it was remained at par with $40 \mathrm{~kg} \mathrm{P}_{2} \mathrm{O}_{5} / \mathrm{ha}+20 \mathrm{~kg} \mathrm{~S} / \mathrm{ha}$ and $30 \mathrm{~kg}$ $\mathrm{P}_{2} \mathrm{O}_{5} / \mathrm{ha}+20 \mathrm{~kg} \mathrm{~S} / \mathrm{ha}$.

The significant increase of $\mathrm{S}$ content in seed and stover was found due to application of phosphorous, sulphur and PSB over no application. This might be attributed to the beneficial effect of phosphorous, sulphur and $S$ addition to the soil. These results are in close agreement with those reported by Serawat et al. (2018) and Raj et al. (2017) in greengram.

\section{Nutrient uptake}

Data pertaining to $\mathrm{N}, \mathrm{P}$ and $\mathrm{S}$ uptake by seed and straw are presented in Table 2.

\section{N, P and S uptake by seed and stover}

The $\mathrm{N}$ uptake by seed and stover (Table 2) were significantly influenced due to different treatments. Significantly the highest N uptake by seed $(26.69 \mathrm{~kg} / \mathrm{ha})$ was obtained under treatment i.e. $50 \mathrm{~kg} \mathrm{P}_{2} \mathrm{O}_{5} / \mathrm{ha}+20 \mathrm{~kg} \mathrm{~S} / \mathrm{ha}+$ $\mathrm{PSB}$, but it was found at par with the treatments of viz., $40 \mathrm{~kg} \mathrm{P}_{2} \mathrm{O}_{5} / \mathrm{ha}+20 \mathrm{~kg} \mathrm{~S} / \mathrm{ha}$

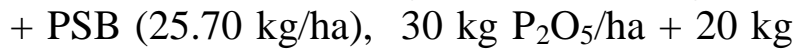

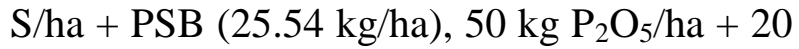
$\mathrm{kg} \mathrm{S} / \mathrm{ha}(24.05 \mathrm{~kg} / \mathrm{ha})$ and $40 \mathrm{~kg} \mathrm{P}_{2} \mathrm{O}_{5} / \mathrm{ha}+20$ $\mathrm{kg} \mathrm{S} / \mathrm{ha}(23.26 \mathrm{~kg} / \mathrm{ha})$. Treatment $30 \mathrm{~kg}$ $\mathrm{P}_{2} \mathrm{O}_{5} /$ ha recorded minimum $\mathrm{N}$ uptake (15.30 $\mathrm{kg} / \mathrm{ha}$ ) by seed. Similarly, significantly higher $\mathrm{N}$ uptake by stover $(10.34 \mathrm{~kg} / \mathrm{ha})$ was obtained

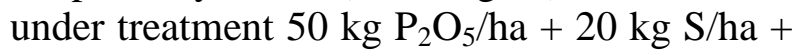
$\mathrm{PSB}$, but it was found at par with the treatments of viz., $40 \mathrm{~kg} \mathrm{P} \mathrm{O}_{5} / \mathrm{ha}+20 \mathrm{~kg} \mathrm{~S} / \mathrm{ha}$ + PSB (10.17 kg/ha), $30 \mathrm{~kg} \mathrm{P}_{2} \mathrm{O}_{5} / \mathrm{ha}+20 \mathrm{~kg}$

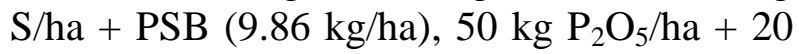

$\mathrm{kg} \mathrm{S} / \mathrm{ha}(8.87 \mathrm{~kg} / \mathrm{ha}), 40 \mathrm{~kg} \mathrm{P}_{2} \mathrm{O}_{5} / \mathrm{ha}+20 \mathrm{~kg}$ $\mathrm{S} / \mathrm{ha}(8.44 \mathrm{~kg} / \mathrm{ha})$ and $30 \mathrm{~kg} \mathrm{P}_{2} \mathrm{O}_{5} / \mathrm{ha}+20 \mathrm{~kg}$ $\mathrm{S} / \mathrm{ha}(8.95 \mathrm{~kg} / \mathrm{ha})$. Treatment of $30 \mathrm{~kg} \mathrm{P}_{2} \mathrm{O}_{5} / \mathrm{ha}$ recorded minimum $\mathrm{N}$ uptake $(7.10 \mathrm{~kg} / \mathrm{ha})$ by stover.

Significantly highest $\mathrm{P}$ uptake by seed (4.86 $\mathrm{kg} / \mathrm{ha})$ and stover $(2.39 \mathrm{~kg} / \mathrm{ha})$ was recorded under treatment $50 \mathrm{~kg} \mathrm{P}_{2} \mathrm{O}_{5} / \mathrm{ha}+20 \mathrm{~kg} \mathrm{~S} / \mathrm{ha}+$ $\mathrm{PSB}$, but it was found at par with the

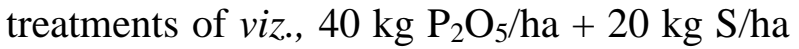
+ PSB (4.63 kg/ha), $30 \mathrm{~kg} \mathrm{P}_{2} \mathrm{O}_{5} / \mathrm{ha}+20 \mathrm{~kg}$ $\mathrm{S} / \mathrm{ha}+\mathrm{PSB}(4.54 \mathrm{~kg} / \mathrm{ha}), 50 \mathrm{~kg} \mathrm{P} \mathrm{O}_{5} / \mathrm{ha}+20$ $\mathrm{kg} \mathrm{S} / \mathrm{ha}(4.45 \mathrm{~kg} / \mathrm{ha})$ and $40 \mathrm{~kg} \mathrm{P}_{2} \mathrm{O}_{5} / \mathrm{ha}+20$ $\mathrm{kg} \mathrm{S} / \mathrm{ha}(4.13 \mathrm{~kg} / \mathrm{ha})$ and in the same trend but in addition it was remained at par with $30 \mathrm{~kg}$ $\mathrm{P}_{2} \mathrm{O}_{5} \mathrm{ha}^{-1}+20 \mathrm{~kg} \mathrm{~S} \mathrm{ha}^{-1}$ for $\mathrm{P}$ uptake in stover. Treatment $30 \mathrm{~kg} \mathrm{P}_{2} \mathrm{O}_{5} /$ ha recorded minimum $\mathrm{P}$ uptake by seed $(2.35 \mathrm{~kg} / \mathrm{ha})$ and stover $(1.51$ $\%)$.

The significantly highest $\mathrm{S}$ uptake by seed $(1.88 \mathrm{~kg} / \mathrm{ha})$ and stover $(1.76 \mathrm{~kg} / \mathrm{ha})$ was recorded under treatment $50 \mathrm{~kg} \mathrm{P}_{2} \mathrm{O}_{5} / \mathrm{ha}+20$ $\mathrm{kg} \mathrm{S} / \mathrm{ha}+\mathrm{PSB}$ (Table 2), but it was found at par with the treatments of viz., $40 \mathrm{~kg} \mathrm{P}_{2} \mathrm{O}_{5} / \mathrm{ha}$ $+20 \mathrm{~kg} \mathrm{~S} / \mathrm{ha}+\mathrm{PSB}, 30 \mathrm{~kg} \mathrm{P}_{2} \mathrm{O}_{5} / \mathrm{ha}+20 \mathrm{~kg}$ $\mathrm{S} / \mathrm{ha}+\mathrm{PSB}$ and $50 \mathrm{~kg} \mathrm{P}_{2} \mathrm{O}_{5} / \mathrm{ha}+20 \mathrm{~kg} \mathrm{~S} / \mathrm{ha}$ and the same trend was also found for stover, but in addition, it was remained at par with 40 $\mathrm{kg} \mathrm{P}_{2} \mathrm{O}_{5} / \mathrm{ha}+20 \mathrm{~kg} \mathrm{~S} / \mathrm{ha}$ and $30 \mathrm{~kg} \mathrm{P}_{2} \mathrm{O}_{5} / \mathrm{ha}+$ $20 \mathrm{~kg} \mathrm{~S} / \mathrm{ha}$ for $\mathrm{S}$ uptake. Treatment of $30 \mathrm{~kg}$ $\mathrm{P}_{2} \mathrm{O}_{5} /$ ha recorded minimum $\mathrm{S}$ uptake by seed $(0.68 \mathrm{~kg} / \mathrm{ha})$ and stover $(0.82 \mathrm{~kg} / \mathrm{ha})$.

The synergetic effect among phosphorous, sulphur and PSB might have favored the better utilization of nutrients.

The higher uptake of $\mathrm{P}$ might be attributed to the favorable influence of PSB in solubilization of native soil to make $\mathrm{P}$ readily available to roots during crop growing season. The higher uptake of these nutrients $(\mathrm{N}, \mathrm{P}$ and S) might be the outcome of increases in the seed and stover yield of greengram. 
Table.1 Effect of phosphorous, sulphur and PSB on yield and monetary returns of kharif greengram

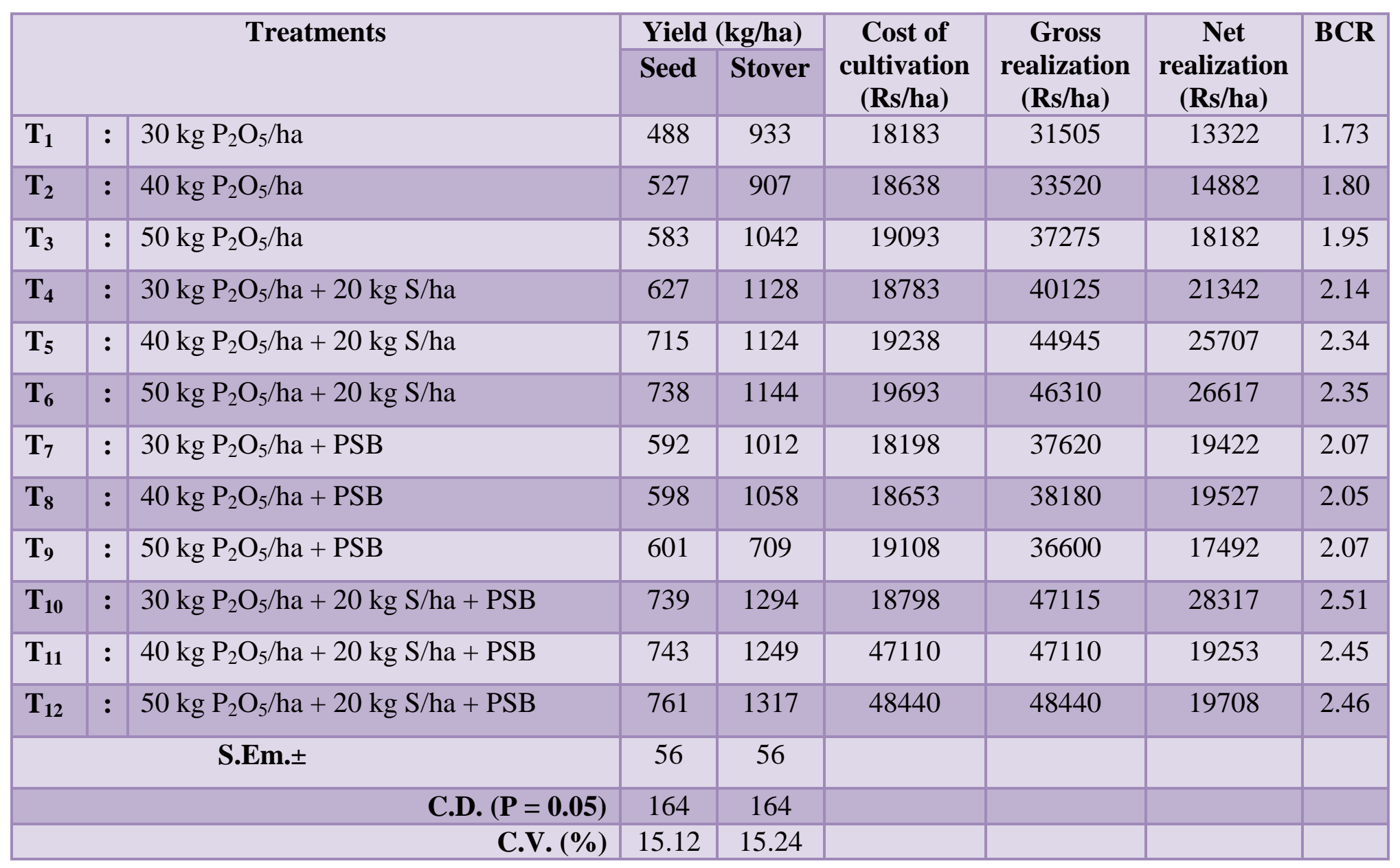


Table.2 Effect of phosphorus, sulphur and biofertilizer on nutrients content and uptake by seed and stover of kharif greengram

\begin{tabular}{|c|c|c|c|c|c|c|c|c|c|c|c|c|c|c|}
\hline \multirow{3}{*}{\multicolumn{3}{|c|}{ Treatments }} & \multicolumn{6}{|c|}{ Nutrients content $(\%)$} & \multicolumn{6}{|c|}{ Nutrients uptake (kg/ha) } \\
\hline & & & \multicolumn{2}{|c|}{ Nitrogen } & \multicolumn{2}{|c|}{ Phosphorus } & \multicolumn{2}{|c|}{ Sulphur } & \multicolumn{2}{|c|}{ Nitrogen } & \multicolumn{2}{|c|}{ Phosphorus } & \multicolumn{2}{|c|}{ Sulphur } \\
\hline & & & Seed & Stover & seed & stover & seed & stovr & seed & stover & seed & stover & seed & Stover \\
\hline $\mathbf{T}_{1}$ & : & $30 \mathrm{~kg} \mathrm{P}_{2} \mathrm{O}_{5} / \mathrm{ha}$ & 3.14 & 0.76 & 0.483 & 0.162 & 0.140 & 0.088 & 15.30 & 7.10 & 2.35 & 1.51 & 0.68 & 0.82 \\
\hline $\mathbf{T}_{2}$ & : & $40 \mathrm{~kg} \mathrm{P}_{2} \mathrm{O}_{5} / \mathrm{ha}$ & 3.17 & 0.76 & 0.526 & 0.163 & 0.162 & 0.091 & 16.66 & 6.88 & 2.78 & 1.47 & 0.85 & 0.83 \\
\hline $\mathbf{T}_{\mathbf{3}}$ & : & $50 \mathrm{~kg} \mathrm{P}_{2} \mathrm{O}_{5} / \mathrm{ha}$ & 3.19 & 0.76 & 0.541 & 0.163 & 0.178 & 0.113 & 18.59 & 7.92 & 3.15 & 1.69 & 1.03 & 1.17 \\
\hline $\mathbf{T}_{4}$ & : & $30 \mathrm{~kg} \mathrm{P}_{2} \mathrm{O}_{5} / \mathrm{ha}+20 \mathrm{~kg} \mathrm{~S} / \mathrm{ha}$ & 3.23 & 0.79 & 0.576 & 0.161 & 0.205 & 0.127 & 20.34 & 8.95 & 3.61 & 1.82 & 1.27 & 1.43 \\
\hline $\mathbf{T}_{5}$ & : & $40 \mathrm{~kg} \mathrm{P}_{2} \mathrm{O}_{5} / \mathrm{ha}+20 \mathrm{~kg} \mathrm{~S} / \mathrm{ha}$ & 3.23 & 0.75 & 0.579 & 0.167 & 0.206 & 0.128 & 23.26 & 8.44 & 4.13 & 1.89 & 1.46 & 1.44 \\
\hline $\mathbf{T}_{6}$ & : & $50 \mathrm{~kg} \mathrm{P}_{2} \mathrm{O}_{5} / \mathrm{ha}+20 \mathrm{~kg} \mathrm{~S} / \mathrm{ha}$ & 3.27 & 0.77 & 0.605 & 0.175 & 0.233 & 0.129 & 24.05 & 8.87 & 4.45 & 2.00 & 1.72 & 1.49 \\
\hline $\mathbf{T}_{7}$ & : & $30 \mathrm{~kg} \mathrm{P}_{2} \mathrm{O}_{5} / \mathrm{ha}+\mathrm{PSB}$ & 3.20 & 0.76 & 0.555 & 0.166 & 0.189 & 0.114 & 18.97 & 7.72 & 3.30 & 1.67 & 1.12 & 1.16 \\
\hline $\mathbf{T}_{8}$ & : & $40 \mathrm{~kg} \mathrm{P}_{2} \mathrm{O}_{5} / \mathrm{ha}+\mathrm{PSB}$ & 3.21 & 0.76 & 0.561 & 0.168 & 0.198 & 0.115 & 19.17 & 8.08 & 3.35 & 1.78 & 1.18 & 1.22 \\
\hline $\mathbf{T}_{9}$ & : & $50 \mathrm{~kg} \mathrm{P}_{2} \mathrm{O}_{5} / \mathrm{ha}+\mathrm{PSB}$ & 3.21 & 0.77 & 0.575 & 0.169 & 0.199 & 0.117 & 19.31 & 5.43 & 3.46 & 1.20 & 1.20 & 0.83 \\
\hline $\mathbf{T}_{10}$ & : & 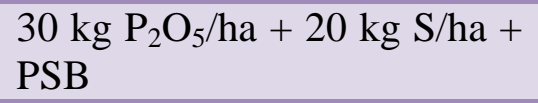 & 3.45 & 0.77 & 0.611 & 0.177 & 0.236 & 0.130 & 25.54 & 9.86 & 4.54 & 2.30 & 1.76 & 1.69 \\
\hline $\mathbf{T}_{11}$ & : & $\begin{array}{l}40 \mathrm{~kg} \mathrm{P}_{2} \mathrm{O}_{5} / \mathrm{ha}+20 \mathrm{~kg} \mathrm{~S} / \mathrm{ha}+ \\
\mathrm{PSB}\end{array}$ & 3.45 & 0.81 & 0.622 & 0.177 & 0.239 & 0.131 & 25.70 & 10.17 & 4.63 & 2.22 & 1.77 & 1.63 \\
\hline $\mathbf{T}_{12}$ & : & 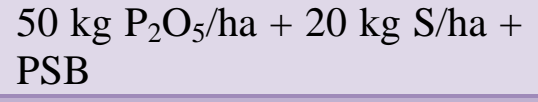 & 3.51 & 0.79 & 0.637 & 0.182 & 0.247 & 0.135 & 26.69 & 10.34 & 4.86 & 2.39 & 1.88 & 1.76 \\
\hline & & S.Em. \pm & 0.08 & 0.02 & 0.016 & 0.005 & 0.006 & 0.003 & 2.10 & 0.71 & 0.37 & 0.18 & 0.12 & 0.13 \\
\hline & & C.D. $(P=0.05)$ & NS & $\mathrm{NS}$ & 0.048 & 0.01 & 0.018 & 0.009 & 6.15 & 2.10 & 1.08 & 0.52 & 0.35 & 0.38 \\
\hline & & C.V. (\%) & 4.45 & 5.13 & 4.92 & 4.73 & 5.17 & 4.65 & 17.19 & 14.89 & 17.1 & 16.66 & 15.7 & 17.40 \\
\hline
\end{tabular}


Table.3 Effect of phosphorus, sulphur and biofertilizer on organic carbon, available $\mathrm{P}_{2} \mathrm{O}_{5}$ and $\mathrm{S}$ content in soil after harvest of kharif greengram

\begin{tabular}{|c|c|c|c|c|c|}
\hline \multirow{2}{*}{\multicolumn{3}{|c|}{ Treatments }} & \multirow{3}{*}{$\begin{array}{c}\text { Organic carbon } \\
(\%)\end{array}$} & \multirow{2}{*}{\multicolumn{2}{|c|}{ Available nutrients }} \\
\hline & & & & & \\
\hline$T_{1}$ & : & $30 \mathrm{~kg} \mathrm{P}_{2} \mathrm{O}_{5} / \mathrm{ha}$ & & $\begin{array}{c}\mathbf{P}_{\mathbf{2}} \mathrm{O}_{\mathbf{5}}(\mathrm{kg} / \mathrm{ha}) \\
41.63\end{array}$ & $\begin{array}{c}\mathrm{S}(\mathrm{mg} / \mathrm{kg}) \\
8.04\end{array}$ \\
\hline $\mathbf{T}_{2}$ & $:$ & $40 \mathrm{~kg} \mathrm{P}_{2} \mathrm{O}_{5} / \mathrm{ha}$ & 0.267 & 41.76 & 8.97 \\
\hline $\mathbf{T}_{3}$ & : & $50 \mathrm{~kg} \mathrm{P}_{2} \mathrm{O}_{5} / \mathrm{ha}$ & 0.280 & 41.77 & 9.13 \\
\hline $\mathbf{T}_{4}$ & : & $30 \mathrm{~kg} \mathrm{P}_{2} \mathrm{O}_{5} / \mathrm{ha}+20 \mathrm{~kg} \mathrm{~S} / \mathrm{ha}$ & 0.300 & 45.62 & 11.18 \\
\hline $\mathbf{T}_{5}$ & : & $40 \mathrm{~kg} \mathrm{P}_{2} \mathrm{O}_{5} / \mathrm{ha}+20 \mathrm{~kg} \mathrm{~S} / \mathrm{ha}$ & 0.303 & 45.92 & 11.24 \\
\hline $\mathbf{T}_{6}$ & : & $50 \mathrm{~kg} \mathrm{P}_{2} \mathrm{O}_{5} / \mathrm{ha}+20 \mathrm{~kg} \mathrm{~S} / \mathrm{ha}$ & 0.287 & 45.94 & 11.98 \\
\hline $\mathbf{T}_{7}$ & : & $30 \mathrm{~kg} \mathrm{P}_{2} \mathrm{O}_{5} / \mathrm{ha}+\mathrm{PSB}$ & 0.297 & 41.95 & 8.17 \\
\hline $\mathbf{T}_{8}$ & : & $40 \mathrm{~kg} \mathrm{P}_{2} \mathrm{O}_{5} / \mathrm{ha}+\mathrm{PSB}$ & 0.297 & 42.34 & 9.07 \\
\hline $\mathbf{T}_{\mathbf{9}}$ & : & $50 \mathrm{~kg} \mathrm{P}_{2} \mathrm{O}_{5} / \mathrm{ha}+\mathrm{PSB}$ & 0.303 & 42.39 & 9.03 \\
\hline $\mathbf{T}_{10}$ & : & $30 \mathrm{~kg} \mathrm{P}_{2} \mathrm{O}_{5} / \mathrm{ha}+20 \mathrm{~kg} \mathrm{~S} / \mathrm{ha}+\mathrm{PSB}$ & 0.310 & 43.33 & 12.11 \\
\hline $\mathbf{T}_{11}$ & $:$ & $40 \mathrm{~kg} \mathrm{P}_{2} \mathrm{O}_{5} / \mathrm{ha}+20 \mathrm{~kg} \mathrm{~S} / \mathrm{ha}+\mathrm{PSB}$ & 0.323 & 44.51 & 12.79 \\
\hline $\mathbf{T}_{12}$ & : & $50 \mathrm{~kg} \mathrm{P} \mathrm{P}_{5} / \mathrm{ha}+20 \mathrm{~kg} \mathrm{~S} / \mathrm{ha}+\mathrm{PSB}$ & 0.293 & 46.63 & 12.94 \\
\hline & & S.Em.土 & 0.014 & 44.51 & 0.49 \\
\hline & & C.D. $(P=0.05)$ & NS & 3.53 & 1.43 \\
\hline & & C.V. $(\%)$ & 7.96 & 4.78 & 8.15 \\
\hline & & Initial & 0.26 & 37.40 & 9.52 \\
\hline
\end{tabular}


The positive effect of phosphorous, sulphur and PSB on N, P and S uptake has also been reported by Serawat et al. (2018) and Raj et al. (2017) in greengram.

\section{Nutrient status of soil after harvest Organic carbon}

The perusal of the data present in Table 3 revealed that the differences in organic carbon content in soil after harvest of greengram crop were found non significant due to different treatments.

\section{Available phosphorus}

A perusal of data presented in Table 3 indicated that available $\mathrm{P}_{2} \mathrm{O}_{5}$ content in soil after harvest of greengram crop differed significantly due to different treatments. The results revealed that an application of $50 \mathrm{~kg}$ $\mathrm{P}_{2} \mathrm{O}_{5} / \mathrm{ha}+20 \mathrm{~kg} \mathrm{~S} / \mathrm{ha}+\mathrm{PSB}$ registered significantly higher available phosphorus content in soil $(46.63 \mathrm{~kg} / \mathrm{ha})$ as compared to other treatments except $T_{1}, T_{2}, T_{3}, T_{7}, T_{8}$ and $\mathrm{T}_{9}$. The lowest available phosphorus content in soil (41.63 kg/ha) was recorded under treatment $30 \mathrm{~kg} \mathrm{P}_{2} \mathrm{O}_{5} / \mathrm{ha}$. It might be due to supply of phosphorous and better mineralization of organic $\mathrm{P}$ under the influence of PSB. Similar findings had been reported by Sipai et al. (2016) in greengram crop.

\section{Available sulphur}

The data pertaining to available sulphur in soil after harvest of greengram crop are presented in Table 2.

The data revealed that the available $\mathrm{S}$ in soil after harvest of greengram crop was significantly influenced due to different treatments. The data narrated in Table 2 indicated that significantly higher S (12.94 ppm) content in soil after harvest of crop was noticed with application of $50 \mathrm{~kg} \mathrm{P}_{2} \mathrm{O}_{5} / \mathrm{ha}+$ $20 \mathrm{~kg} \mathrm{~S} / \mathrm{ha}+\mathrm{PSB}$, but it was found at par with the treatments of viz., $40 \mathrm{~kg} \mathrm{P}_{2} \mathrm{O}_{5} / \mathrm{ha}+20$

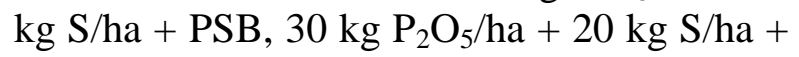
PSB and $50 \mathrm{~kg} \mathrm{P}_{2} \mathrm{O}_{5} / \mathrm{ha}+20 \mathrm{~kg} \mathrm{~S} / \mathrm{ha}$. The lower $\mathrm{S}(8.04 \mathrm{mg} / \mathrm{kg})$ content in soil after harvest of crop was found under the treatment $30 \mathrm{~kg} \mathrm{P}_{2} \mathrm{O}_{5} / \mathrm{ha}$. The significant improvement in available sulphur status of soil was found in treatments which had received sulphur nutrition. This was might be due to beneficial effect of sulphur fertilizer on available $S$ content in soil and $\mathrm{S}$ addition to the soil. The results are in accordance with those reported by Patel et al. (2014) in greengram.

\section{Economics}

The data on cost of cultivation, gross and net realization as well as benefit : cost ratio (B : C ratio) for different treatments are presented in Table 1.

A perusal of data on gross realization as influenced by different treatments revealed that the maximum gross realization of 48440/ha was accrued under the treatment $50 \mathrm{~kg} \mathrm{P}_{2} \mathrm{O}_{5} / \mathrm{ha}+20 \mathrm{~kg} \mathrm{~S} / \mathrm{ha}+\mathrm{PSB}$ followed by treatment $30 \mathrm{~kg} \mathrm{P}_{2} \mathrm{O}_{5} / \mathrm{ha}+20 \mathrm{~kg} \mathrm{~S} / \mathrm{ha}+$ PSB ( 47115/ha). The highest net realization of `28317/ha and benefit : cost ratio (BCR) of 2.51 were obtained with the treatment $30 \mathrm{~kg}$ $\mathrm{P}_{2} \mathrm{O}_{5} / \mathrm{ha}+20 \mathrm{~kg} \mathrm{~S} / \mathrm{ha}+\mathrm{PSB}$.

In view of the results obtained from the present investigation, it could be concluded that for securing higher seed yield and net realization of greengram (cv. Gujarat Mungbean 4) raised on loamy sand under dry land conditions, the crop should be fertilized with phosphorus@30 kg/ha, sulphur @20 $\mathrm{kg} / \mathrm{ha}$ with PSB (phosphorus solubilizing bacteria) liquid biofertilizer along with recommended dose of $\mathrm{N} @ 20 \mathrm{~kg} / \mathrm{ha}$ along with sustaining soil fertility. 


\section{References}

Chauhan, B.S., Stewart, J.S.B. and Paul, E.A. (1997). Effect of carbon additions on soil labile in organic, organic and microbial held phosphate. Canadian Journal of Soil Science. 59 : 387-396.

Das, S.K. (2017). Effect of phosphorus and sulphur on yield attributes, yield, nodulation and nutrient uptake of green gram [Vigna radiata (L.) Wilczek]. Legume Research. 40 (1) : 138-143.

DE and S (2018-19). Directorate of Economics and Statistics, Department of Agriculture and Co-operation, New Delhi.

DOA (2018-19). Second Advance Estimates of Area, Production and Yield of Major khariflrabi crops of Gujarat State, Directorate of Agriculture, Gujarat State, Gandhinagar.

Goswami, N.N. (1988). Sulphur In Indian Agriculture. Proc. of TSI-FAI symposium. On Sulphur in Indian Agriculture, New Delhi. pp. 1-90.

Manju, Rani., Ved, P. and Khan, K. (2016). Response of mungbean [Vigna radiata (L.) Wilczek] to phosphorus, sulphur and PSB. Agricultural Sciences Digest. 36 (2) : 146-148.

Marchner, H. (1995). Mineral Nutrition of Higher Plants. $2^{\text {nd }}$ Ed. Academic Press, San Diego.

Panse, V.G. and Sukhatme P.V. (1985). Statistical Method for Agricultural workers, Indian Council of Agricultural Research (ICAR), New Delhi.

Parveen, S., Mohammad Sagir, K. and Almas, Z. (2002). Effect of rhizospheric microorganism on growth and yield of green gram. Indian Journal of Agricultural Science. 72 (7) : 421-423.

Patel, H.K, Patel P.M., Suthar J.V and Patel M.R. (2014). Yield and quality of postharvest nutrient status of chickpea as influence by application of sulphur phosphorus and biofertilizer fertilizer management. Indian Journal of Scientific and Research Publication. 4 (7) : 2250-3153.

Patel, H.R., Patel, H.F., Maheriya, V.D. and Dodiya, I.N. (2013). Response of Kharif greengram [Vigna radiata (L.) Wilczek] to sulphur and phosphorus fertilization with and without biofertilizer application. The Bioscan. 8 (1) : 149-152.

Raj, S., Choudhry R. and Jat, B. (2017). Effect of biofertilizer different level of phosphorus and sulphur on growth and yield of greengram [Vigna radiata (L.) Wilczek]. International Journal of Agricultural Science. 13 (2) : 390-402.

Randall, P.J. (1988). Evolution of the Sulphur Status of Soils and Plants.

Technique and interpretation. Proc. of TSI-FAI Symposium. Sulphur in Indian Agriculture. new Delhi. pp. SI (1-15).

Serawat, A., Sharma, Y., Serawat, M., Kapoor, A. and Jakhar, R.K. (2018). Effect of phosphorus and sulphur on growth attributes and yield of greengram (Vigna radiata L.) of Hyper Arid Western Plains of Rajasthan. International Journal of Current Microbiology and Applied Sciences. 7 (8) : 2674-2683.

Sipai, A.H., Jat, J.R. and Rathore, B.S. (2016). Effect of phosphorus, sulphur and biofertilizer on growth, yield and nodulation in mungbean on loamy sand soils of Kachchh. Crop Research. 51 (1) : 18-29.

Theodorou, M.E. and Plaxton, W.C. (1993). Metabolic adaptations of plant respiration to nutritional phosphate deprivation. Plant Physiology. 101 : 339-344. 


\section{How to cite this article:}

Komalben K. Bhabhor, Nandkishor I. Patel, Brijal R. Patel and Chaudhary, M. M. 2019. Response of Greengram (Vigna radiata L. Wilczek) to Nutrients Influencing Yield, Uptake and Soil Fertility in Loamy Sand Soil under Dry Land Condition. Int.J.Curr.Microbiol.App.Sci. 8(10): 2048-2057. doi: https://doi.org/10.20546/ijcmas.2019.810.238 